\title{
REVIEWS
}

\section{Novel Bioceramic Root Repair Materials: Review of the Literature}

\section{Nowe materiały bioceramiczne do naprawy korzenia - przegląd piśmiennictwa}

Department of Conservative and Pediatric Dentistry, Wroclaw Medical University, Wrocław, Poland

A - research concept and design; $\mathbf{B}$ - collection and/or assembly of data; $\mathbf{C}$ - data analysis and interpretation;

$\mathbf{D}$ - writing the article; $\mathbf{E}$ - critical revision of the article; $\mathbf{F}$ - final approval of article

\begin{abstract}
Bioceramics are specially designed ceramic materials, which, due to their properties such as biocompatibility, bioactivity and a range of physical features, are applied in a variety of medical and dental procedures. The first bioceramic used with success in dentistry was Mineral Trioxide Aggregate, which then became the "golden standard" in endodontics. MTA, however, despite its wide acknowledgement, has several inconvenient clinical drawbacks. To overcome those obstacles the novel bioceramic materials like Biodentine ${ }^{\circledR}$, BioAggregate ${ }^{\circledR}$, Calcium Enriched Mixture and EndoSequence ${ }^{\circledR}$ were introduced to the market.

In this paper the characteristics of those materials were described in regards to their impact on composition and its influence on the materials' features, physical properties such as setting time, radiopacity, compressive and pushout bond strength, sealing ability and biological attributes such as bioactivity and biocompatibility. Based on the available publications those materials have a broad range of possible clinical applications which cover root repair procedures such as root-end filing, open apex management or perforation repair, vital pulp therapy as well as regenerative endodontics. Some of them may also be used as canal sealers. Nonetheless, there is still need for further research to confirm the long-term performance of those novel materials (Dent. Med. Probl. 2016, 53, 4, 551-558).
\end{abstract}

Key words: mineral trioxide aggregate, ceramics, Biodentine ${ }^{\circledR}$, BioAggregate ${ }^{\circledR}$, EndoSequence ${ }^{\circledR}$ root repair material.

Słowa kluczowe: mineralny agregat trójtlenków metali, ceramika, Biodentine ${ }^{\circledR}$, BioAggregate ${ }^{\circledR}$, EndoSequence ${ }^{\circledR}$.

Bioceramics are specially designed ceramic materials, which, due to their physical and biological properties, such as biocompatibility, bioactivity and a range of physical features, are successfully used for a variety of medical and dental procedures. The term "ceramics" covers inorganic nonmetalic solids comprising metal, non-metal or metalloid atoms primarily held in ionic or covalent bonds [1]. With such a wide definition, many materials that previously were not considered or advertised as bioceramic may be added to this group. This applies to one of the most acknowledged endodontic materials - Mineral Trioxide Aggregate (MTA).

MTA is the first bioceramic cement successfully used in endodontics. It was introduced in the early 90 s as a material for perforations and retro- grade obturation [2]. Chemically, it is a calcium silicate material, based on Portland cement with the addition of bismuth oxide as a radiopacifier [2] (Table 1). Although the clinical efficacy of MTA is well established, the material exhibits some drawbacks such as a long setting time, difficult handling, limited resistance to washout before setting and a risk of tooth discoloration associated with the presence of bismuth oxide $[1,3]$. To overcome these disadvantages, novel bioceramic root repair materials were developed.

Biodentine $^{\circledR}$ (Septodont, St. Maur-des-Fossés, France) is a material composed of synthetic tricalcium silicate as a substitute for Portland cement, zirconium oxide which replaces bismuth oxide and some additives that include calcium carbonate, di- 
Table 1. The composition of materials described in the article

\begin{tabular}{|c|c|c|c|c|c|}
\hline & MTA & Biodentine & $\begin{array}{l}\text { Calcium Enriched } \\
\text { Mixture }\end{array}$ & BioAggregate & EndoSequence \\
\hline $\begin{array}{l}\text { Cement } \\
\text { composition }\end{array}$ & $\begin{array}{l}\text { tricalcium silicate } \\
\text { dicalcium silicate } \\
\text { tricalcium alumi- } \\
\text { nate } \\
\text { bismuth oxide } \\
\text { (radiopacifier) }\end{array}$ & $\begin{array}{l}\text { tricalcium silicate } \\
\text { dicalcium silicate } \\
\text { zirconium oxide } \\
\text { (radiopacifier) } \\
\text { calcium carbonate } \\
\text { (filler) } \\
\text { iron oxides } \\
\text { (shade) }\end{array}$ & $\begin{array}{l}\text { calcium hydroxide } \\
\text { calcium oxide } \\
\text { calcium phosphate } \\
\text { calcium sulfate } \\
\text { calcium silicate } \\
\text { calcium carbonate }\end{array}$ & $\begin{array}{l}\text { tricalcium silicate } \\
\text { dicalcium silicate } \\
\text { tantalum pentoxide } \\
\text { (radiopacifier) } \\
\text { calcium phosphate } \\
\text { monobasic } \\
\text { amorphous silicon } \\
\text { oxide }\end{array}$ & $\begin{array}{l}\text { calcium silicates } \\
\text { calcium phos- } \\
\text { phate mono- } \\
\text { basic } \\
\text { zirconium oxide } \\
\text { and tantalum } \\
\text { oxide (radi- } \\
\text { opacifiers) }\end{array}$ \\
\hline $\begin{array}{l}\text { Liquid } \\
\text { composition }\end{array}$ & distilled water & $\begin{array}{l}\text { water } \\
\text { calcium chloride } \\
\text { (accelerator) } \\
\text { hydrosoluble poly- } \\
\text { mer (polycar- } \\
\text { boxylate) (water } \\
\text { reducing agent) }\end{array}$ & distilled water & deionized water & \\
\hline
\end{tabular}

calcium silicate, calcium oxide and iron oxide in powder form and calcium chloride and a water reducing agent in the liquid form $[1,4]$. The composition of Biodentine influences some of its properties. The use of pure synthetic tricalcium silicate, instead of purifying the natural tricalcium silicate is beneficial for the quality of the material [4]. The changes in formulation resulted also in the reduction of setting time and a decrease in radiopacity.

Calcium Enriched Cement (BioniqueDent, Tehran, Iran), which was previously referred to as NEC (Novel Endodontic Cement), was introduced by Asgary et al. [5] in 2006 as a root-end filling material. CEM is a white powder that sets in the presence of the water solution (e.g. distilled water). It is composed of different calcium compounds, i.e. calcium hydroxide, calcium oxide, calcium phosphate, calcium sulphate, calcium silicate, and calcium carbonate [6].

BioAggregate $^{\circledR}$ (Innovative Bioceramix, Vancouver, Canada) was introduced to the dental market as the first nanoparticular mineral material. According to the manufacturer it is produced under controlled conditions to form a pure, contamination-free white hydraulic powder composed of bioceramic nanoparticles. The composition of BioAggregate is similar to MTA with some differences, e.g. it contains tentalum oxide instead of bismuth oxide. Moreover, it shows the presence of another cement type, specifically calcium phosphate [1].

EndoSequence $^{\circledR}$ (ERRM) (Brassler USA, Savannah, USA) is commercially available as a root repair material (as both a putty and a syringable paste) or as a canal sealer. In Europe those materials are being distributed as TotalFill ${ }^{\circledR}$ (FKG Dentaire, La Chaux-de-Fonds, Switzerland) [1]. They are developed in a pre-mixed form to provide the clinicians with a homogeneous paste, which influences both physi- cal properties and the ease of use. The presence of moisture is required for the material to set and harden. However, according to the producer the moisture present in the dentinal tubules should be sufficient. EndoSequence is composed of calcium silicates, calcium phosphate monobasic and includes zirconium oxide and tantalum oxide as radiopacifiers [1]. There is also the $\operatorname{iRoot}^{\circledR}$ (Innovative Bioceramix, Vancouver, Canada) family on the market: iRoot BP in preloaded syringes, iRoot BP Plus in jars with thicker consistency, iRoot FS which sets faster and injectable root canal sealer iRoot SP. The composition of these materials is identical to EndoSequence [7].

\section{Search Methodology}

A review of literature from peer-reviewed journals was conducted by searching the PubMed database using key words: "bioceramics", "Biodentine", "Calcium Enriched Mixture","BioAggregate" and "EndoSequence". All retrieved articles published until April 2016 were analyzed and classified according to the topic that they cover. Finally, the best matching references were selected with the focus on the most recent publications.

\section{A Review of Literature}

\section{Physical Properties}

\section{Setting Time}

The setting time is one of the most relevant clinical factors. Long-setting cement may cause clinical problems because of its inability to maintain shape and support stresses during this period. Therefore, a bioceramic material that has op- 
timal mechanical behavior and sets fast would be attractive to the clinician in specific clinical situations. According to the research, Biodentine has the shortest setting time when compared with MTA and BioAggregate [8-10], which is the result of adding calcium chloride to the liquid and calcium carbonate (filler component often used as a hydration accelerator) to the powder [8]. In a study by Guo et al. [3] the setting time of EndoSequence putty was compared with grey and white MTA and a recently introduced fast-setting bioceramic paste: iRoot FS. According to this research, ERRM putty has similar results to grey MTA, white MTA sets a little bit faster, but iRoot FS definitely stands out from other tested materials having the shortest both initial and final setting time. Thus, it may be considered as an alternative in specific clinical situations in which the material's period of setting should be as brief as possible.

\section{Radiopacity}

The proper radiopacity of endodontic material is essential to effectively evaluate its position or homogeneity in X-rays in clinical practice. This feature directly depends on the metal oxide included in the composition of the material. So far, MTA containing bismuth oxide as a radiopacifier is matchless. According to Ahmetoglu et al. [11], the radiopacity of Biodentine is similar but slightly inferior to BioAggregate and significantly lower than that of MTA. Nevertheless, all values exceeded the minimum standard according to ISO, which equals $3 \mathrm{~mm} \mathrm{Al}$. In another, more recent study, however, the radiopacity value of Biodentine was found to be only $1.5 \mathrm{~mm} \mathrm{Al}$, which is definitely too low for clinical use and thus should be improved [9]. CEM also demonstrates lower radiopacity than different types of MTA, which is indeed higher than the radiopacity of dentine (1 mm Al), but may also be insufficient [12].

\section{Compressive Strength}

Another essential physical feature of the material is its compressive strength (CS), which is especially significant when the material may be directly or indirectly subjected to masticatory forces, e.g. in furcal perforation repair. It is one of the indicators of the setting and strength of a material [3]. In a study by Butt at al. [10], CS of Biodentine was found to be much higher than that of MTA. Jang et al. [8] confirmed that CS of Biodentine is superior to both MTA and BioAggregate. The authors attributed the great results to the low water/ cement ratio. The compressive strength of CEM is also higher than that of MTA and may be affected by the mixing method [13]. BioAggregate, in turn, compared to other bioceramic materials has the weakest CS results and that is most probably directly associated with the high water-to-powder ratio [8]. As far as EndoSequence is concerned, its compressive strength is significantly higher than white and grey MTA [3].

\section{Push-out Bond Strength}

An ideal bioceramic cement should have the ability to adhere to dentinal walls in order to resist the dislodging forces. As far as Biodentine is concerned, its push-out bond strength is similar to MTA and higher than BioAggregate [14]. In turn, the dislodgement resistance of CEM is lower than MTA [15]. EndoSequence stands out from other described materials. It has higher bond strength to the root canal than MTA and BioAggregate [16]. Moreover, the dislocation resistance of the putty form does not seem to be influenced by environmental acidity, unlike MTA and ERRM paste [17]. Favorable physical characteristics may be associated with the filler agents in ERRM putty, its ability to thicken, as well as with the presence of zirconium oxide, which has been reported to improve certain properties of bioceramics [17].

To facilitate the comparison of the described materials properties, their physical features with exact references were gathered in Table 2.

\section{Sealing Ability}

Failure in endodontic treatment is caused by microorganisms and their by-products penetrating obturated root canal systems. Therefore, the ideal root repair material should provide a threedimensional hermetic seal between the inner and outer tooth environment, especially in furcal perforation repair, open apices management or retrograde filling (Table 3).

\section{Marginal Adaptation Studies}

Scanning electron microscopy studies analyzing the marginal adaptation of the biomaterials to dentinal walls show that there is no significant difference between MTA, Biodentine, BioAggregate and CEM [18]. Moreover, the blood contamination does not affect their sealing ability [18]. Similarly, EndoSequence, when compared with MTA, showed equal adaptation at dentin-material interface [19].

\section{Microleakage Studies}

Various test methods have been used to determine the sealing ability of bioceramics, such as bacteria infiltration, fluid filtration, dye penetration or dye extraction method. Thus, the microleakage results often vary depending on the technique applied. 
Table 2. The selected physical properties of the described materials (in order to simplify the table standard deviation values were omitted)

\begin{tabular}{|c|c|c|c|c|c|c|}
\hline $\begin{array}{l}\text { Conditions of } \\
\text { the study }\end{array}$ & MTA & Biodentine & $\begin{array}{l}\text { BioAg- } \\
\text { gregate }\end{array}$ & EndoSequence & $\begin{array}{l}\text { Calcium Enriched } \\
\text { Mixture }\end{array}$ & References \\
\hline \multicolumn{7}{|c|}{ setting time $(\mathrm{min})$} \\
\hline & 275 & 15 & 385 & & & Jang et al. [8] \\
\hline Initial setting & 8.5 (Angelus MTA) & 6.5 & & & & Butt et al. [10] \\
\hline Final setting & 228.33 (ProRoot MTA) & 85.66 & & & & Kaup et al. [9] \\
\hline $\begin{array}{l}\text { Initial setting } \\
\text { Final setting }\end{array}$ & $\begin{array}{l}58.3 \text { (GMTA) } \\
42.2 \text { (WMTA) } \\
217.2 \text { (GMTA) } \\
139.6 \text { (WMTA) }\end{array}$ & & & $\begin{array}{l}61.6 \text { (putty) } \\
18.3 \text { (iRoot FS) } \\
208 \text { (putty) } \\
57 \text { (iRoot FS) } \\
\end{array}$ & & Guo et al. [3] \\
\hline \multicolumn{7}{|c|}{ radiopacity $(\mathrm{mm} \mathrm{Al})$} \\
\hline & 5.9 (MM-MTA) & 3.42 & 3.78 & & & $\begin{array}{l}\text { Ahmetoglu } \\
\text { et al. [11] }\end{array}$ \\
\hline & 6.4 (ProRoot MTA) & 1.5 & & & & Kaup et al. [9] \\
\hline & $\begin{array}{l}5.589 \text { (Angelus MTA) } \\
5.519 \text { (Root MTA) } \\
5.009 \text { (ProRoot MTA) }\end{array}$ & & & & 2.227 & $\begin{array}{l}\text { Torabzadeh } \\
\text { et al. [12] }\end{array}$ \\
\hline \multicolumn{7}{|c|}{ compressive strength $(\mathrm{MPa})$} \\
\hline $\begin{array}{l}1 \text { hour } \\
1 \text { day } \\
7 \text { days } \\
28 \text { days }\end{array}$ & $\begin{array}{l}0 \\
41.51 \\
91.35 \\
76.82 \\
\end{array}$ & $\begin{array}{l}138.5 \\
170.78 \\
269.08 \\
304.78 \\
\end{array}$ & & & & Butt et al. [10] \\
\hline $\begin{array}{l}1 \text { day } \\
3 \text { days } \\
7 \text { days }\end{array}$ & $\begin{array}{l}36.67 \\
48.51 \\
57.51\end{array}$ & $\begin{array}{l}61.35 \\
62.57 \\
62.64\end{array}$ & $\begin{array}{l}17.65 \\
20.52 \\
22.03\end{array}$ & & & Jang et al. [8] \\
\hline 21 hours & $\begin{array}{l}151.33 \text { (hand) } \\
156.78 \text { (amalgamator) }\end{array}$ & & & & $\begin{array}{l}257.33 \text { (hand) } \\
211.50 \text { (amalgamator) }\end{array}$ & $\begin{array}{l}\text { Shahi } \\
\text { et al. [13] }\end{array}$ \\
\hline 21 days & $\begin{array}{l}257.00 \text { (hand) } \\
249.33 \text { (amalgamator) }\end{array}$ & & & & $\begin{array}{l}238.33 \text { (hand) } \\
249.33 \text { (amalgamator) }\end{array}$ & \\
\hline $\begin{array}{l}7 \text { days } \\
28 \text { days }\end{array}$ & $\begin{array}{l}47.8 \text { (GMTA) } \\
49.6 \text { (WMTA) }\end{array}$ & & & $\begin{array}{l}107.4 \\
176.6\end{array}$ & & Guo et al. [3] \\
\hline \multicolumn{7}{|c|}{ push-out bond strength $(\mathrm{MPa})$} \\
\hline & 23.26 (WMTA) & 21.86 & 9.57 & & & $\begin{array}{l}\text { Alsubait et al. } \\
{[14]}\end{array}$ \\
\hline & 5.94 & & & & 1.68 & Adi et al. [15] \\
\hline $\begin{array}{l}1 \text { week } \\
2 \text { months }\end{array}$ & $\begin{array}{l}2.61 \\
8.4\end{array}$ & & $\begin{array}{l}2.1 \\
7.25\end{array}$ & $\begin{array}{l}11.7 \\
17.79\end{array}$ & & $\begin{array}{l}\text { Shokouhinejad } \\
\text { et al. [16] }\end{array}$ \\
\hline $\begin{array}{l}\mathrm{pH}=7.4 \\
\mathrm{pH}=4.4\end{array}$ & $\begin{array}{l}11.45 \\
7.21\end{array}$ & & & $\begin{array}{l}12.33 \text { (putty) } \\
9.97 \text { (paste) } \\
11.81 \text { (putty) } \\
7.28 \text { (paste) }\end{array}$ & & $\begin{array}{l}\text { Shokouhinejad } \\
\text { et al. [17] }\end{array}$ \\
\hline
\end{tabular}

Biodentine applied as an apical plug in immature teeth has been proven to be equally effective as MTA, regardless of the plug thickness [20]. In this study the fluid filtration technique was used. However, when Biodentine was compared with EndoSequence and MM-MTA with the application of dye extraction method, it had the worst results, while EndoSequence performed the best [21]. Dye penetration studies concerning the sealing ability of Calcium Enriched Mixture proved that, as a retrograde filling, it is equally effective as dif- ferent commercial types of MTA [5]. The fluid filtration method used by Mirhadi et al. [22] confirmed that statement and showed that in neutral $\mathrm{pH}$ there is no difference between MTA and CEM as apical plugs, but in alkaline environment the microleakage of MTA is greater. According to Bayram et al. [23], the sealing ability of BioAggregate as a root-end filling is also similar to that of MTA and may be influenced by the irrigants: increased by EDTA and MTAD and decreased by $\mathrm{CHX}$ and distilled water. In another study, how- 
Table 3. Marginal adaptation and microleakage studies of the described materials (in order to simplify the table standard deviation values were omitted)

\begin{tabular}{|c|c|c|c|c|c|c|}
\hline $\begin{array}{l}\text { Conditions of } \\
\text { the study }\end{array}$ & MTA & Biodentine & BioAggregate & EndoSequence & $\begin{array}{l}\text { Calcium } \\
\text { Enriched } \\
\text { Mixture }\end{array}$ & References \\
\hline \multicolumn{7}{|c|}{ marginal adaptation $(\mathrm{SEM})(\mu \mathrm{m})$} \\
\hline \multirow{2}{*}{$\begin{array}{l}\text { Normal saline } \\
\text { Blood contami- } \\
\text { nation }\end{array}$} & $\begin{array}{l}0.81 \\
1.36\end{array}$ & $\begin{array}{l}0.5 \\
1.58\end{array}$ & $\begin{array}{l}0.66 \\
1.53\end{array}$ & & $\begin{array}{l}1.13 \\
1.36\end{array}$ & $\begin{array}{l}\text { Bolhari et al. } \\
\text { [18] }\end{array}$ \\
\hline & 4.25 & & & $\begin{array}{l}2.78 \text { (putty) } \\
4.8 \text { (paste) }\end{array}$ & & $\begin{array}{l}\text { Shokouhinejad } \\
\text { et al. [19] }\end{array}$ \\
\hline \multicolumn{7}{|c|}{$\begin{array}{l}\text { microleakage } \\
\text { method }\left(\mu \mathrm{L} \cdot \mathrm{cm} \mathrm{H}_{2} \mathrm{O}^{-1} \cdot \min ^{-1}\right)\end{array}$} \\
\hline $\begin{array}{l}\text { apical plug } \\
\text { at } 1 \mathrm{~mm} \\
\text { at } 2 \mathrm{~mm} \\
\text { at } 3 \mathrm{~mm} \\
\text { at } 4 \mathrm{~mm}\end{array}$ & $\begin{array}{l}2.39 \\
1.98 \\
0.67 \\
0.56\end{array}$ & $\begin{array}{l}2.03 \\
1.85 \\
0.71 \\
0.6\end{array}$ & & & & Bani et al. [20] \\
\hline $\begin{array}{l}\text { apical plug } \\
\text { Alkaline pH } \\
\text { Neutral pH }\end{array}$ & $\begin{array}{l}4.1 \\
3.3 \\
\end{array}$ & & & & $\begin{array}{l}2.4 \\
2.1\end{array}$ & $\begin{array}{l}\text { Mirhadi et al. } \\
{[22]}\end{array}$ \\
\hline $\begin{array}{l}\text { root-end filling } \\
\text { Distilled water } \\
\text { CHX } \\
\text { EDTA } \\
\text { MTAD }\end{array}$ & $\begin{array}{l}0.000494 \\
0.000548 \\
0.000644 \\
0.000685 \\
\end{array}$ & & $\begin{array}{l}0.000455 \\
0.000514 \\
0.000801 \\
0.000737\end{array}$ & & & $\begin{array}{l}\text { Bayram et al. } \\
{[23]}\end{array}$ \\
\hline \multicolumn{7}{|c|}{ 2) dye penetration method ( $\mathrm{mm})$} \\
\hline root-end filling & $\begin{array}{l}1.402 \text { (Root MTA) } \\
1.705 \text { (WMTA) } \\
1.720 \text { (Angelus } \\
\text { MTA) }\end{array}$ & & & & 1.247 & $\begin{array}{l}\text { Asgary et al. } \\
{[5]}\end{array}$ \\
\hline root-end filling & 0.8 & & 0.6 & & & $\begin{array}{l}\text { Sayed and } \\
\text { Saeed [24] }\end{array}$ \\
\hline \multicolumn{7}{|c|}{ 3) dye extraction method (absorbance values) } \\
\hline $\begin{array}{l}\text { perforation } \\
\text { repair }\end{array}$ & $\begin{array}{l}0.0721(\mathrm{MM}- \\
\text { MTA) }\end{array}$ & 0.0757 & & 0.0682 & & $\begin{array}{l}\text { Jeevani et al. } \\
\text { [21] }\end{array}$ \\
\hline
\end{tabular}

ever, with the application of different microleakage determination method (dye extraction), BioAggregate's results were superior to MTA, which, according to the authors, may be explained by the presence of nanoparticles that achieve excellent adhesion to the dentin and by its hydrophilic nature that results in setting expansion [24].

\section{Biological Properties}

\section{Bioactivity}

A bioactive material is able to interact with living tissues, resulting in biomineralization at the material-tissue interface [25], thus leading to regeneration and healing. Biodentine was proved to be bioactive by measuring the amount of calcium and silicone ions and carbonate incorporated from the material to the adjacent dentin in the presence of PBS (phosphate-buffered solution). The study showed the presence of tag-like structures extend- ing from the material to dentinal tubules, leading to the formation of the so-called "mineral infiltration zone", where the alkaline products of the material's hydration degrade the collagenous component of the adjacent dentin. This degradation leads to the creation of a porous structure, which facilitates the penetration of high concentrations of ions, leading to increased mineralization in this region [26]. Other research indicated the deposition of hydroxyapatite on the surface of Biodentine when exposed to HBBS (Hank's Balanced Salt Solution) [4]. Nevertheless, it was Kim et al. [27] who first evaluated the interfacial characteristics of Biodentine with dentin in stimulated body fluid, which has ion concentrations most similar to the body tissues. The study confirmed the bioactivity of Biodentine; however, TEM analysis of the interfacial layer showed the presence of amorphous calcium phosphate but no hydroxyapatite. Also, the thickness of the interfacial layer of 
Biodentine was lower in comparison to MTA [27]. As far as Calcium Enriched Mixture, in turn, releases hydroxyl $\left(\mathrm{OH}^{-}\right)$, calcium $\left(\mathrm{Ca}^{2+}\right)$ and phosphate $\left(\mathrm{PO}^{4-}\right)$ ions, which then form hydroxyapatite in the presence of stimulated body fluid or saline solution. At the same time, it promotes alkaline $\mathrm{pH}$ of $\sim 9.5-11$ in the similar manner as MTA [6]. This process proves the bioactivity of CEM. Shokouhinejad et al. [25] compared the performance of BioAggregate, EndoSequence and MTA when exposed to PBS. It resulted in the precipitation of apatite crystals that increased over time at the surface of all the tested materials, which suggests their bioactivity. However, the most recently conducted research shows that when in contact with tissue fluids, EndoSequence does not encourage the formation of hydroxyapatite on its surface (as was claimed by previous in vitro studies). The presence of carbon dioxide in vivo leads to the formation of calcium carbonate instead. Moreover, the environmental conditions, such as the presence of blood, affect the hydration of ERRM and consequently its interaction with the tissues [28].

\section{Biocompatibility}

Biocompatibility of the dental material is an important factor, specifically when it is supposed to be in direct contact with the connective tissue and has potential influence on the viability of pulpal or periradicular cells. Thus, many studies, both in vivo and in vitro have been conducted to evaluate the cytotoxicity of the bioceramic materials.

\section{In vitro Studies}

Some of the studies concentrate on the effect on human periodontal ligament fibroblasts (hPDL) to mimic the clinical situations, such as perforation repair or root-end filling, in which the material is in direct contact with periodontal tissues. According to the majority of this research, there is no statistically significant difference in terms of cytotoxicity between MTA and Biodentine [8], Calcium Enriched Mixture [29], BioAggregate [8] or EndoSequence [30]. However, the research by Jang et al. [8] reveals that in comparison to MTA and BioAggregate, Biodentine releases significantly higher amounts of heavy metals (arsenic, copper, iron, manganese and zinc) when soaked in distilled water. Nevertheless, the plausible clinical consequences are not yet clear.

\section{In vivo Studies}

In vivo evaluation carried out in subcutaneous tissues of rats concerning the inflammatory response induced by Biodentine proved that it is biocompatible [31]. In turn, the study, testing osseous reaction to implantation of two endodontic cements: MTA and CEM, presents similar histologic response to both materials and the formation of osseous, cementum-like tissue in their vicinity, which suggests their cytocompatibility and a regenerative potential [32]. BioAggregate was also proven to have excellent biocompatibility in $v i$ vo, when used as a perforation repair material in dogs [33]. According to this research, there is no significant difference in inflammatory response, epithelial proliferation and new hard tissue formation between BioAggregate and MTA. As far as EndoSequence is concerned, studies conducted by Chen et al. [34] revealed a superior healing after root-end surgery in dogs associated with EndoSequence rather than MTA. Nevertheless, this could have been detected only by CBCT or micro CT. One of the most valuable studies available is the one by Shinbori et al. [35]. The authors examined the clinical results of endodontic surgery with the application of EndoSequence as a root-end filling material. They analyzed clinical records and radiographs of 113 cases with minimum 1-year follow-up. The success rate was $92 \%$, which suggests that EndoSequence may be a successful alternative to MTA for a retrograde obturation.

\section{Stem Cells Studies}

The most recent studies concentrate on the effect of endodontic materials on stem cells, and they evaluate their possible application in regenerative endodontics, which aims to become an alternative to the traditional root canal treatment. That research evaluates the ability of endodontic cements to promote osteogenic differentiation of stem cells that may directly lead to the regeneration of pulpdentin complex. So far, the researchers evaluated in vitro the effect of Biodentine on human dental pulp stem cells (hDPSCs) [36] or stem cells of human apical papilla (SCAP) [37]. They all concluded that Biodentine is biocompatible and enhances the proliferation, migration, adhesion as well as osteoblast differentiation of stem cells. Similarly, CEM has similar effect on human pulp stem cells as MTA [38] and they both induce osteo-/ odontogenic differentiation of these cells, thus enabling regeneration. In turn, when compared with MTA and Biodentine, CEM showed the lowest cytotoxicity in regard to stem cells of human apical papilla [37]. The research conducted by Jung et al. [39] shows that BioAggregate also stimulates odontoblastic differentiation of human dental pulp cells (HDPCs) and thus induces mineralization. According to Machado et al. [40], the influence of EndoSequence on the differentiation of dental pulp cells is also similar to MTA. All of these studies suggest that new bioceramic materials may be applied in regenerative endodontics procedures. 


\section{Clinical Applications}

Based on the cited publications, newly introduced bioceramic materials may be considered as alternatives to Mineral Trioxide Aggregate for the wide variety of clinical applications. Due to their proper biological and physical characteristics, they may be successfully used as root repair materials in procedures such as retrograde obturation after a root resection $[5,24,35]$, open apices management with an apical plug $[20,22]$ or root perforation repair $[21,33]$. Thanks to the excellent biocompatibility and bioactivity, they may also be used in vital pulp therapy in endodontic procedures, such as indirect pulp capping or pulpotomy. Moreover, bioceramics may be applied in regenerative endodontics, which is a new, quickly expanding branch of conservative dentistry that aims to substitute traditional endodontic treatment. Numerous stem cell studies confirm their possible application in regenerative procedures, such as revascularization [36, 38-40]. In addition, some of the bioceramic materials, such as EndoSequence $\mathrm{BC}$ sealer, TotalFill BC or iRoot SP, are specially designed to serve as root canal sealers for the final canal obturation [1].

\section{Conclusion}

To conclude, newly introduced bioceramic root repair materials, such as Biodentine, Calcium Enriched Mixture, BioAggregate or EndoSequence, may be considered as an alternative to Mineral Trioxide Aggregate, which is currently the golden standard in endodontics. The review of literature shows that they succeeded in overcoming some of the drawbacks associated with MTA and that they may replace it in the variety of clinical applications. With further studies confirming their long-term performance, bioceramic cements have the potential to become the preferred materials for various endodontic procedures.

\section{References}

[1] Camilleri J.: Is mineral trioxide aggregate a bioceramic? Int. J. Dent. Sci. 2016, 18, 13-17.

[2] Camilleri J.: The chemical composition of mineral trioxide aggregate. J. Conserv. Dent. 2008, 11, 141-143.

[3] Guo Y., Du T., Li H., Shen Y., Mobuchon C., Hieawy A., Wang Z., Yang Y., Ma J., HaApasalo M.: Physical properties and hydration behavior of a fast-setting bioceramic endodontic material. BMC Oral Health 2016, doi: 10.1186/s12903-016-0184-1.

[4] Camilleri J., Sorrentino F., Damidot D.: Investigation of the hydration and bioactivity of radiopacified tricalcium silicate cement, Biodentine and MTA Angelus. Dent. Mater. 2013, 29, 580-593.

[5] Asgary S., Eghbal M., Parirokh M., Torabzadeh H.: Sealing ability of three commercial mineral trioxide aggregates and an experimental root-end filling material. Iran. Endod. J. 2006, 1, 101-105.

[6] Ghazvivni S., Tabrizi M., Kobarfard F., Baghban A., Asgary S.: Ion release and pH of a new endodontic cement, MTA and Portland cement. Iran. Endod. J. 2009, 4, 74-78.

[7] Tanomaru M., Viapiana R., Guerreiro J.: From MTA to new biomaterials based on calcium silicate. Int. J. Dent. Sci. 2016, 18, 18-22.

[8] Jang Y., Lee B., Koh J., Park Y., Joo N., Chang H., Hwang I., Oh W., Hwang Y.: Cytotoxicity and physical properties of tricalcium silicate-based endodontic materials. Restor. Dent. Endod. 2014, 39, 89-94.

[9] Kaup M., Schafer E., Dammaschke T.: An in vitro study of different material properties of Biodentine compared to ProRoot MTA. Head Face Med. 2015, doi: 10.1186/s13005-015-0074-9.

[10] Butt N., Talwar S., Chaudhry S., Nawal R., Yadav S., Bali A.: Comparison of physical and mechanical properties of mineral trioxide aggregate and Biodentine. Indian J. Dent. Res. 2014, 25, 692-697.

[11] Ahmetoglu F., Simsek N., Keles A., Sinan M. Ocak, Altun O.: Radiopacity evaluation of three calcium silicatebased materials by digital radiography. Clin. Dent. Res. 2013, 37, 32-37.

[12] Torabzadeh H., Aslanzadeh S., Asgary S.: Radiopacity of various dental biomaterials. Res. J. Biol. Sci. 2012, 7, $152-158$.

[13] Shahi S., Ghasemi N., Rahimi S., Yavari H., Samiei M., Janani M., Bahari M., Moheb S.: The effect of different mixing methods on the flow rate and compressive strength of mineral trioxide aggregate and calcium-enriched mixture. Iran. Endod. J. 2015, 10, 55-58.

[14] Alsubait S., Hashem Q., Alharhan N., Almohimeed K., Alkahtani A.: Comparative evaluation of push-out bond strength of ProRoot MTA, BioAggregate and Biodentine. J. Contemp. Dent. Pract. 2014, 15, 336-340.

[15] Adi A., Sobhnamayan F., Kazemi O.: Comparison of push-out bond strength of mineral trioxide aggregate and calcium enriched mixture cement as root end filling materials. Dent. Res. J. 2014, 11, 564-567.

[16] Shokouhinejad N., Razmi H., Nekoofar M., Sajadi S., Dummer P., Khoshkhounejad M.: Push-out bond strength of bioceramic materials in a synthetic tissue fluid. J. Dent. (Tehran) 2013, 10, 540-547.

[17] Shokouhinejad N., Yazdi K., Nakoofar M., Matmir S., Khoshkhounejad M.: Effect of acidic environment on dislocation resistance of EndoSequence root repair material and mineral trioxide aggregate. J. Dent. (Tehran) 2014, 11, 161-166. 
[18] Bolmari B., Yazdi K., Sharifi F., Pirmoazen S.: Comparative scanning electron microscopic study of the marginal adaptation of four root-end filling materials in presence and absence of blood. J. Dent. (Tehran) 2015, 12, $226-234$.

[19] Shokouhinejad N., Nekoofar M., Ashoftehyazdi K., Zahraee S., Koshkhounejad M.: Marginal adaptation of new bioceramic materials and mineral trioxide aggregate: A scanning electron microscopy study. Iran Endod. J. $2014,9,144-148$.

[20] Bani M., Sungurtekin E.-Ekci, Odabas M.: Efficacy of Biodentine as an apical plug in nonvital permanent teeth with open apices: An in vitro study. Biomed. Res. Int. 2015, doi: 10.1155/2015/359275.

[21] Jeevani E., Jayaprakash T., Bolla N., Vemuri S., Sunil C., Kalluru R.: Evaluation of sealing ability of MM-MTA, EndoSequence, and Biodentine as furcation repair materials: UV spectrophotometric analysis. J. Conserv. Dent. 2014, 17, 340-343.

[22] Mirhadi H., Moazzami F., Jahromi S., Safarzade S.: The effects of alkaline pH on microleakage of mineral trioxide aggregate and calcium enriched mixture apical plugs. J. Dent. (Shiraz) 2016, 17, 16-20.

[23] Bayram H., Saklar F., Bayram E., Orucoglu H., Bozkurt A.: Determination of the apical sealing abilities of mineral trioxide aggregate, Portland cement and BioAggregate after irrigation with different solutions. J. Int. Oral Health, 2015, 7, 13-17.

[24] SAyEd E., SAEED M.: In vitro comparative study of sealing ability of Diadent BioAggregate and other root-end filling materials. J. Conserv. Dent. 2012, 15, 249-252.

[25] Shokouhinejad N., Nekoofar M., Razmi H., Sajadi S., Davies T., Saghiri M., Gorjestani H., Dummer P.: Bioactivity of EndoSequence Root Repair material and BioAggregate. Int. Endod. J. 2012, 45, 1127-1134.

[26] Aтmen A., Chong E., Richard G., Festy F., Watson T.: Dentin-cement interfacial interaction: Calcium silicates and polyalkenoates. J. Dent. Res. 2012, 91, 454-459.

[27] Kim J., Nosrat A., Fouad A.: Interfacial characteristics of Biodentine and MTA with dentine in simulated body fluid. J. Dent. 2015, 43, 241-247.

[28] Moinzadeh A., Aznar C. Portoles, Schembri P. Wismayer, Camilleri J.: Bioactivity potential of EndoSequence BC RRM Putty. J. Endod. 2016, 42, 615-621.

[29] Naghavi N., Ghoddusi J., Sadeghnia H., Asadpour E., Asgary S.: Genotoxicity and cytotoxicity of mineral trioxide aggregate and calcium enriched mixture cements on L929 mouse fibroblast cells. Dent. Mat. J. 2014, 33, 64-69.

[30] Willershausen I., Wolf T., Kasaj A., Weyer V., Willershausen B., Marroquin B.: Influence of a bioceramic root end material and mineral trioxide aggregates on fibroblasts and osteoblasts. Arch. Oral Biol. 2013, 58, 1232-1237.

[31] Da T. Fonseca, Da G. Silva, Tanomaru M.-Filho, Sasso E.-Cerri, Guerreiro J.-Tanomaru, Cerri P.: In vivo evaluation of the inflammatory response and IL-6 immunoexpression promoted by Biodentine and MTA Angelus. Int. Endod. J. 2016, 49, 145-153.

[32] Rahimi S., Mokhtari H., Shahi S., Kazemi A., Asgary S., Eghbal M., Mesgariabbasi M., Mohajeri D.: Osseous reaction to implantation of two endodontic cements: mineral trioxide aggregate (MTA) and calcium enriched mixture (CEM). Med. Oral Patol. Oral Cir. Bucal. 2012, 17, 907-911.

[33] Hassanien E., Авu A.-Seida, Hashem A., Khanbash S.: Histologic evaluation of furcation perforation treated with mineral trioxide aggregate and BioAggregate. Asian J. Anim. Sci. 2015, 9, 148-156.

[34] Chen I., Karabucak B., Wang C., Wang H., Koyama E., Kohli M., Nah H., Kim S.: Healing after root-end microsurgery by using mineral trioxide aggregate and a new calcium silicate-based bioceramic material as root-end filling materials in dogs. J. Endod. 2015, 41, 389-399.

[35] Shinbori N., Grama A., Patel Y., Woodmansey K., He J.: Clinical outcome of endodontic microsurgery that uses EndoSequence BC root repair material as the root-end filling material. J. Endod. 2015, 41, 607-612.

[36] Bortoluzzi E., Miu L., Palani C., El-Awady A.R, Hammond B., Pei D., Tian F., Cutler C., Pashley D., TAY F.: Cytotoxicity and osteogenic potential of silicate calcium cements as potential protective materials for pulpal revascularization. Dent. Mater. 2015, 31, 1510-1522.

[37] Saberi E., Karkehabadi H., Mollashahi N.: Cytotoxicity of various endodontic materials on stem cells of human apical papilla. Iran Endod. J. 2016, 11, 17-22.

[38] Jaberiansari Z., Naeri S., Tabatabaei F.: Cytotoxic effects of various mineral trioxide aggregate formulations, calcium-enriched mixture and a new cement on human pulp stem cells. Iran. Endod. J. 2014, 9, 271-276.

[39] Jung J., Woo S., Lee B., KoH J., Nor J., Hwang Y.: Effect of Biodentine and BioAggregate on odontoblastic differentiation via mitogen-activated protein kinase pathway in human dental pulp cells. Int. Endod. J. 2015, 48, 177-184.

[40] Machado J., Johnson J., Paranjpe A.: The effects of EndoSequence Root Repair Material on differentiation of dental pulp cells. J. Endod. 2016, 42, 101-105.

\section{Address for correspondence:}

Dagna Brzęcka

Department of Conservative and Pediatric Dentistry

Wroclaw Medical University

Krakowska 26

Conflict of Interest: None declared

50-425 Wrocław

Poland

Tel.: 717840361

E-mail: dagna.brzecka@gmail,com

Received: 25.05.2016

Revised: 13.06 .2016

Accepted: 29.06.2016 